\title{
Defensive burying: A cross-species replication and extension
}

\author{
STEPHEN F. DAVIS, DAVID A. WHITESIDE, DOUGLAS G. HECK, \\ and VIRGINIA A. DICKSON \\ Emporia State University, Emporia, Kansas 66801
}

and

JAMES L. TRAMILL

Wichita State University, Wichita, Kansas 67208

\begin{abstract}
Five experiments investigating the display of defensive burying by Mongolian gerbils and mice are reported. Adult gerbils failed to engage in defensive burying when the aversive stimulus consisted of a flashbulb (Experiment 1), an electric shock (Experiment 2), and a chemical substance (Experiment 3). Young gerbils also failed to engage in burying under the flashbulb condition (Experiment 4). Mice, however, engaged in burying under the flashbulb condition (Experiment 5).
\end{abstract}

The defensive burying paradigm essentially consists of one presentation of an aversive stimulus. Following this presentation, the animal may be tested immediately or removed and tested at a later time for conditioned defensive burying. Typically, the amount of time spent in burying behavior and the height of burying material accumulated around the aversive stimulus are reported as dependent variable measures.

Pinel and his collaborators (e.g., Pinel \& Treit, 1979; Terlecki, Pinel, \& Treit, 1979) have shown that hooded rats will bury a variety of aversive stimuli (e.g., an electric shock prod, a flashbulb, a mouse trap, and a tube that delivered an airblast) and use a variety of material (e.g., commercial bedding material, sand, and cubes of wood) in this behavior. Research in our laboratory (Davis \& Rossheim, 1980; Davis, Whiteside, Dickson, Thomas, \& Heck, Note 1; Davis, Whiteside, Thomas, \& Heck, Note 2) has also shown that the burying response is sensitive to injections of drugs such as insulin, Thorazine, and Elavil, the type of aversive stimulus employed (electric shock vs. discharge of a flashbulb), and whether or not the subjects are tested individually or in pairs.

Sources such as Priniciples of Animal Psychology (Maier \& Schneirla, 1935), "The Snark Was a Boojum" (Beach, 1950), "Polythetic Biopsychology: An Alternative to Behaviorism" (Jensen, 1970), and Comparative Animal Behavior (Dewsbury, 1978) have argued effectively for approaches to the study of animal behavior that have the effect of increasing the quantity and quality of information gained. "Animal psychologists have come to

This research was supported in part by a grant from the Research and Creativity Committee of Emporia State University to the first author. Portions of this paper were presented at the meeting of the Psychonomic Society, St. Louis, Missouri, November 1980. recognize the potential distortions of natural behavior that can occur in the laboratory, the importance of field studies, and the value of work with a variety of nondomesticated species" (Dewsbury, 1978, p. 26). Hence, an additional aspect of contemporary defensive burying research has been a concern for the generality of this phenomenon beyond the hooded or albino rat. For example, Treit, Terlecki, and Pinel (1980) have recently reported the results of three experiments in which variables such as species, strain, and age of subject were investigated. Based on the results of these studies, it was concluded that (1) Mongolian gerbils and Syrian golden hamsters did not actively engage in defensive burying (Experiment 1), (2) male and female Long-Evans rats did not differ in the display of burying behavior (Experiments 1 and 3), (3) strain differences influenced the amount of observed burying in both rats and mice (Experiment 2), and (4) age of subject influenced the amount of burying shown by Long-Evans rats (Experiment 3).

As a single electric shock delivered by a stationary prod was the only aversive stimulus employed by Treit et al. (1980), it would seem of some importance to test subjects, such as the Mongolian gerbil, under a variety of aversive conditions before concluding that defensive burying is not shown by this species. The present series of experiments sought to investigate such conditions.

\section{GENERAL METHOD}

As the same apparatus and general method were employed in all studies to be discussed, they will be described only at this point.

\footnotetext{
Apparatus

Testing took place in a rectangular $(25 \mathrm{~cm}$ wide, $45 \mathrm{~cm}$ long, $30 \mathrm{~cm}$ high) enclosure (more fully described in Davis \&
} 
Rossheim, 1980). In all cases, the bedding material (San-I-Cel; Paxton Processing Company, Paxton, Illinois) composing the floor of the chamber was $4.00 \mathrm{~cm}$ deep. The device (more fully described in Davis \& Rossheim, 1980) used to present electric shock and flashbulb stimuli was mounted in the center of an end wall of the chamber, $1 \mathrm{~cm}$ above the floor. Other aversive stimuli employed are described in the specific experimental context.

\section{Procedure}

As all subjects were housed in cages having bedding floors, it was determined that habituation periods to this material were not required. Hence, the general procedure for testing a subject consisted of a 15-min session in the test apparatus to determine a burying baseline. No aversive stimulus presentation occurred during this baseline period. Twenty-four hours later, the subject was returned to the testing chamber, the aversive stimulus was presented, and the occurrence of burying during the ensuing 15 -min period was recorded.

Two observers, using Standard electric timers, independently recorded the amount of time spent in defensive burying (moving material toward or over the aversive stimulus) during baseline and test sessions. At the completion of these sessions, the height of material accumulated at three points (left, right, and center), each located $3 \mathrm{~cm}$ from the stimulus object, was recorded. Since the floor of the testing chamber was smoothed to a uniform $(4.00-\mathrm{cm})$ height prior to the testing of each subject, it was possible to calculate the exact height of additional bedding material that was accumulated.

\section{EXPERIMENTS 1-3}

Adult (120- to 150-day-old) male Mongolian gerbils served as subjects in Experiments 1-3. The discharge of an M-3 flashbulb served as the aversive stimulus in Experiment $1 \quad(n=10)$. The application of a single $5.00-\mathrm{mA}$ electric shock by a stationary shock prod served as the aversive stimulus in Experiment $2(n=11)$. The occurrence of defensive burying was not observed in any animal during either the baseline or the test session of Experiments 1 and 2.

Because Pinel, Treit, and Terlecki (Note 3) have indicated that rats will bury an anesthetized rat that has a small amount of putrescine on it, a chemical stimulus, skatole, was employed in Experiment $3(n=10)$. Skatole, a crystalline compound $\left(\mathrm{C}_{9} \mathrm{H}_{9} \mathrm{~N}\right)$ found with indole in the instestines and feces, was applied to a wood block ( 2 by 2 by $6 \mathrm{~cm}$ ) that extended $2 \mathrm{~cm}$ above the bedding material floor during defensive burying sessions. (The block, without skatole, was present during baseline testing.) As in Experiments 1 and 2, defensive burying was not observed during baseline or test sessions. ${ }^{1}$

\section{EXPERIMENT 4}

The results of Experiments 1-3 corroborate the Treit et al. (1980) findings and suggest that defensive burying may, in fact, not be a behavior in the repertoire of the adult Mongolian gerbil. As visual (discharge of the flashbulb, Experiment 1), tactual (electric shock, Experiment 2), and olfactory (skatole, Experiment 3) modalities were insulted, the suggestion that an effective stimulus was not employed would appear somewhat tenuous. On the other hand, Greenberg (1978) and Greenberg and Dieffenbacher (1976) have reported that old (26 weeks) gerbils were not capable of learning a visual discrimination, whereas young (8 weeks) gerbils were. Given these results, the testing of young gerbils in the defensive burying situation might be expected to result in burying. Eleven young (27-45 days) gerbils were tested for defensive burying in Experiment 4, with the discharge of an M-3 flashbulb serving as the aversive stimulus. (Since Greenberg, 1978, and Greenberg and Dieffenbacher, 1976, employed a visual task in their studies of old vs. young gerbils, the use of a visual stimulus in the defensive burying situation appeared most appropriate.) As in Experiments 1-3, no animal exhibited defensive burying during the baseline or test session (see Footnote 1).

\section{EXPERIMENT 5}

As mentioned, Treit et al. (1980) also demonstrated that one application of an electric shock was sufficient to elicit defensive burying in several strains of mice. Experiment 5 was designed to test for the presence of defensive burying in mice when the discharge of a flashbulb served as the aversive stimulus. Eleven male nonalbino BALB hybrid mice, obtained from the colony maintained by the biology department at Emporia State University, served as subjects. The general testing procedure used in Experiments 1-4 was also employed in Experiment 5. As a high degree of agreement $(r=.95)$ existed between the two observers regarding the amount of time each subject engaged in defensive burying during the baseline and test sessions, the two burying times for each subject were averaged before graphing and statistical analysis. A single score representing the height of bedding material accumulated around the aversive stimulus was obtained for each subject by averaging the left, right, and center measurements taken after each subject was tested. These scores were used for graphing and analysis purposes. Group means reflecting the time spent in burying and the height of bedding material accumulated around the
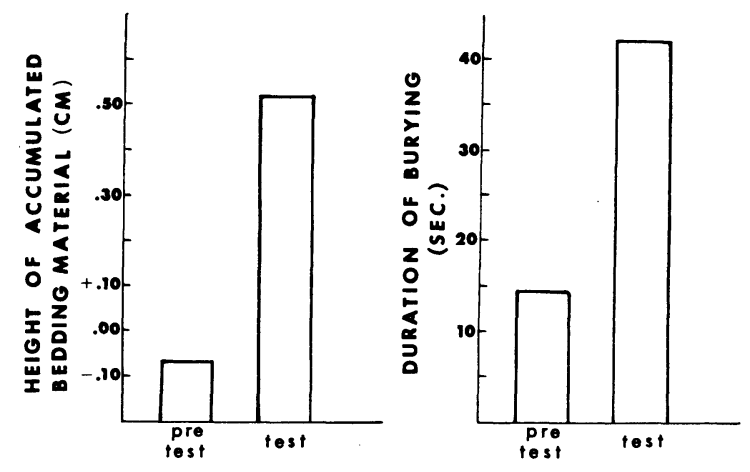

Figure 1. Mean height of accumulated bedding material (left) and mean time (in seconds) spent in defensive burying (right) during baseline and test sessions, Experiment 5. 
aversive stimulus during baseline and test sessions are shown in Figure 1. Analyses (one-tailed $t$ tests for related samples) indicated that the mice spent significantly more time engaged in defensive burying $[t(10)=$ $2.28, \mathrm{p}<.025]$ and accumulated significantly more bedding material around the aversive stimulus $[\mathrm{t}(10)=$ $2.99, \mathrm{p}<.01$ ] during the test session than during the baseline period.

\section{GENERAL DISCUSSION}

The finding that adult gerbils did not bury an electric shock prod (Experiment 2) replicates the Treit et al. (1980) data. The findings that neither young (Experiment 4 ) nor old (Experiment 1) gerbils buried the flashbulb stimulus and that the skatole-covered block was also not buried by the adult gerbils (Experiment 3) extend the previous data and lend support to the contention that defensive burying may well not be a behavior in the gerbil's repertoire. (The absence of burying when sand was used as the flooring material is also supportive of this interpretation.)

A close correspondence between the present data and that reported by Treit et al. (1980) is also reflected in the burying data of the mice. In both studies, subjects engaged in defensive burying for approximately $50 \mathrm{sec}$ during the 15 -min test session that followed application of the aversive stimulus. This average time is in sharp contrast with group means of 150-200 sec that we have observed in our rat subjects (Davis \& Rossheim, 1980). Such differences might be interpreted as reflecting different intensities of the burying response in these two species. However, as our test chamber was used for both rats and mice, such differences may well be attributed to relative size differences in the apparatus. In support of this position, Pinel, Treit, Ladak, and MacLennan (1980) recently demonstrated that increasing the floor dimensions of the test chamber significantly reduced both the duration of burying and the height of accumulated bedding material.

\section{REFERENCE NOTES}

1. Davis, S. F., Whiteside, D. A., Dickson, V. A., Thomas, R. L., \& Heck, D. G. Conditioning and retention of defensive burying as a function of Elavil and Thorazine injection. Unpublished manuscript, 1980

2. Davis, S. F., Whiteside, D. A., Thomas, R. L., \& Heck, D. G. Cooperative defensive burying: Fact or fancy? Unpublished manuscript, 1980.
3. Pinel, J. P. J., Treit, D., \& Terlecki, L. J. Selected filmed sequences of conditioned defensive hurving in the rat. Paper presented at the annual meeting of the Psychonomic Society. Phoenix, Arizona, November 1979.

\section{REFERENCES}

Bнach, F. A. The snark was a boojum. American Psychologist, 1950, 5, 115-124.

Davis, S. F., \& Rossheim, S. A. Defensive burying as a function of insulin-induced hypoglycemia and type of aversive stimulation. Bulletin of the Psychonomic Society, 1980, 16, 229-231.

Dewsbury, D. A. Comparative animal behavior. New York: McGraw-Hill, 1978

Greenberg, G. Failure to observe visual discrimination in old gerbils: Replication report. Journal of General Psychology, 1978, 99, 169-171.

Greenberg, G., \& Dieffenbacher, I. Visual discrimination in the Mongolian gerbil (Meriones unguiculatus) as a function of age. Journal of General Psychology, 1976, 94, 19-22.

Jensen, D. D. Polythetic biopsychology: An alternative to behaviorism. In J. H. Reynierse (Ed.), Current issues in animal learning. Lincoln: University of Nebraska Press, 1970.

Maier, N. R. F., \& Schneirla, T. C. Principles of animal psychology. New York: McGraw-Hill, 1935.

Pinel, J. P. J., \& Treit, D. Conditioned defensive burying in rats: Availability of burying materials. Animal Learning \& Behavior, 1979, 7, 392-396.

Pinel, J. P. J., Treit, D., Ladak, F., \& Maclennan, A. J. Conditioned defensive burying in rats free to escape. Animal Learning \& Behavior, 1980, 8, 447-451.

Terlecki, L. J., Pinel, J. P. J., \& Treit, D. Conditioned and unconditioned defensive burying in the rat. Learning and Motivation, 1979, 10, 337-350.

Treit, D., Terlecki, L. J., \& Pinel, J. P. J. Conditioned defensive burying: Organismic variables. Bulletin of the Psychonomic Society, 1980, 16, 451-454.

\section{NOTE}

1. In an attempt to ascertain whether or not the type of burying material influenced the display of defensive burying in the gerbils, the subjects from Experiments 1 and 4 were retested with a $4.00-\mathrm{cm}$ sand floor replacing the San-I-Cel. The discharge of an M-3 flashbulb served as the aversive stimulus. Burying was not observed in any subject under these conditions.

(Received for publication December 17, 1980.) 